\title{
The Antecedents of Organizational Citizenship Behavior (OCB) and TheirEffect on Performance:Study on Public University in Makassar, South Sulawesi, Indonesia
}

\author{
Wardhani Hakim, Umar Nimran, Siti Haerani, Syamsu Alam \\ Economic and Bussines Faculty, Hasanuddin University, Makassar, South Sulawesi, Indonesia \\ Administration Faculty, Brawijaya University, Malang, South Java, Indonesia \\ Economic and Bussines Faculty Hasanuddin University, Makassar, South Sulawesi, Indonesia \\ Economic and Bussines Faculty Hasanuddin University, Makassar, South Sulawesi, Indonesia
}

\begin{abstract}
Thepurpose of this research is to examine and analyze the effect of personality, organizational commitment, job satisfaction and organizational support on Organizational Citizenship Behavior (OCB) and its implication on lecturers's performance. The approach taken is quantitative study on lecturers of 3 (three) Public University in Makassar, South Sulawesi, Indonesia. Data analyzed with Structural Equation Modelling (SEM) dengan alpha 5\% to examine the relationship between variables.The study reveal that personality, job satisfaction, organizational support, has significant effect on $O C B$ and performance of lecturers. Meanwhile, organizational commitment has significant affect on performance and show negative effect on OCB. Moreover, $O C B$ has significant effect on performance of lecturers.The research variables were measured based on the perception of the respondents who were also the subject of research that can lead to bias in obtaining the data, especially for measuring personality, $O C B$, and performance. Personality and commitment of lecturers in this studymaynotreflectthe personality and commitment in general lecturer at universities throughout Indonesia so it can not be generalized. OCB and performance of lecturers in this study is local, particular at the State University in the city of Makassar and therefore can not be generalized.
\end{abstract}

Keywords: Personality, organizational commitment, job satisfaction and organizational support, Organizational Citizenship Behavior (OCB) and performance.

\section{Introduction}

The term organizational citizenship behavior (OCB) was first proposed by Organ (1998) by stating the 5 dimensions of altruism, civic virtue, conscientiousness, courtesy and sportsmanship. Organizations need employees who would be willing to do the work exceeds a predetermined job description organization. OCB is considered important because it can increase the effectiveness of the organization (Cohen and Vigoda, 2000). The fact about slow development of OCB theory stated by Konovsky and Pugh((1994) which is then amplified by Podsakoffet al., (1996) who stated that the research on OCB are still in the early stage, therefore the research on the antecedents or factors that build up OCB becoming more important.

OCB research was originally conducted in the area of business organizations, particularly manufacturing companies.However, in the development, OCB research has been conducted outside thearea of a business organization. OCB research has been conducted on students who are enrolled in colleges (Allison et al., 2001; Comeau and Griffith, 2005), hospital nurses (Wagner and Rush, 2000), customers (Castro et al. , 2004), school teachers (Feather and Rauter, 2004) and the military leaders (Liang, 2007). However, there are limited numbers of studies that discuss the factors that influence OCB which will ultimately affect the performance of university professors.

\section{Literatur Review}

\subsection{The Impact of personality on $\mathrm{OCB}$ and performance}

Kumar and Bakhshi (2009) found that there was a factor of four relationsof 'big five' that influence

OCB. Using regression the research indicated that Conscientiousness, Extraversion, Neuroticism and Agreeblenesssignificantlyaffect $\mathrm{OCB}$ while openess to experienceindicated the contrary effect. Research by Elanain (2007), examined the effect of the Big Five personality on OCB once controlled by the controling variables such as work locus of control (WLOC), self-esteem, organizational justice.In general, the findings of this research were the Five Factor Model is a predictor of employees OCB.

Emmerik and Euwena (2007) conducted a study to examine the relationship between personality and the three types of OCB, as well as testing the effectiveness of the leadership group as the moderating factor. This study involves 286 teachers as respondents. The study found that the more open extraversion teachers who are more open to experience will be more involve with OCB compare to introversion teachers who are less open 
to experience.Teachers who obtain high scores on conscientiousness characterized as more careful and responsible, thus teachers with introverted and neurotic personalities are less involved in the OCB than that of the extrovert and emotional stability.

King et al. (2005), examined the relationship between personality and the helping behaviors in the workplace. The study utilizeda sample of 374 women who are members of the association of construction. This study found that strongconscientiousnesshave positive influence on helping behavior of individual, high emotional stability and conscientiousness with the relationship between helping behavior is not supported by openness to experience.

Zeithaml (1996) research on the live of creative people suggests that creative people have a more complex personality than others. The personality leads to different thoughts and ultimately leads to new useful ideas and indicates the effect on the performance of creative individuals.

Barrack and Mount (1991) conducted a study on five different professions, namely: professionals, police, managers, sales and technical personnel examiningthe influences of the big five personality on performance. Thedimensions of conscientiousness have a relationship with the fifth profession, while extraversion and openness to experience are related to two professional sales managers and subsequently aggrebleness and emotional stability relate only to the police and technical personnel. This study concludes that there is a significant relationship with the big five personality performance.

A study conducted by Caligiuri (2006)indicated that extraversion, agreeableness and emotional stability had a negative relationship, while conscientiousness and openness to experience has a positive relationship with performance.

Nikolaou (2003) stated that personality dimensions significantly influence individual achievement. The research conducted Lau and Shaffer (1999) also showed that personality has a significant impact on career success. Guthrie et al. (1998) suggest that personality dimensions determine a person's success in managing his career. In general, the results of these studies indicated that personality with multiple dimensions determines a person's success in career success, good performance, achievement and positive behavior. Positive personality traits such as love working together, innovative, open, organized, persistent in their work, and emotionally stable will determine a person's success both in work and learning.

\subsection{The Impact of Organizational Commitment on OCB and Performance}

Wagner and Rush (2000), Ackfeldt and Coote (2000), Gautamet al. (2004), Watts and Levy (2004) found that organizational commitment which includes affective commitment, normative commitment and commitment continuance effect on OCB. Similarly, Kim (2006) found that affective commitment has a positive effect on Altruism and Compliance (OCB). Paulinet al. (2006) studied the organizational climate and commitment to service and how it relates to the interests of customers. This study found that organizational commitment has bigger influence on OCB compare to customer behavior. While Alotaibi (2001) found that there is no influence of organizational commitment to OCB.

Also Chen and Francesco (2003) examined the relationship between the three components of commitment and employee performance. Researchers found that affective commitment has a positive effect on performance and OCB. However Continuance commitment has no effect onperformance and OCB.

Cropanzano et al (2003) suggested that there is a relationship between OCB and performance moderated by organizational commitment. Liang and Huang (2007) found that organizational commitment moderate the relationship between age and job performance and low commitment has negative effect on performance. While Foote and Tang (2008) find that the effect on the team's commitment and OCB, and that the relationship between job satisfaction and OCB is moderated by commitment.

\subsection{The Impact of Job Satisfaction on OCB and Performance}

Alotaibi (2001), conducted a study about the antecedents of OCB such as job satisfaction, organizational commitment, and perceptions of fairness. The study found that procedural justice and distributive justice has positive effect on Organizational Citizenship Behavior (OCB), however job satisfaction and organizational commitment has no effect on OCB.On the contrary,Kim (2006) examines the relationship between motivation, job satisfaction and commitment and OCB. The study revealed that there was positive relationship between OCB and motivation and commitment and negative on job satisfaction.

Koys (2001), Yoon and Suh (2003), Begum (2005), Gonzales and Garazo (2006), Foote and Tang (2008) found employee satisfaction effect on OCB. Vroom (1960) and Strauss (1968) in the study about the relationship between job satisfaction and performance stating that productivity can be improved through increased job satisfaction, job satisfaction because it gives encouragement to workers to increase productivity. Supported by Schleicher (2004) finding that there is a relationship between job satisfaction and performance. The same thing put forward by wanous (2004) that there is a positive relationship intrinsic job satisfaction and extrinsic job satisfaction on performance. 


\subsection{The Impact of Organizational Support on OCB and Performance}

Chen (2005) conducted a study that shows a positive relationship between perceived organizational supports (POS) with extra-role behavior performance. In line withSimon J. Bell (2004), Rhoadhes and Einsenberger (2002)

hip between Shore and Wayne (1993) in his research illustrates that perceived organizational support is a variable that affects OCB. Support organization with three main indicators, namely fairness, support and reward effective supervisor is deemed crucial in improving OCB.

Asgariet al. (2008), conducted a study to examine the relationsorganizational characteristics, job characteristics, cultural context and OCB. They found that perceptions of organizational support and trust as mediators between job characteristics and $\mathrm{OCB}$, and that there is a positive and direct relationship between task characteristics and OCB. Also that the power distance culture is positively and directly related to the OCB and individualism- collectivism had no significant effect with OCB.

\subsection{The influence of OCB on Performance}

Research by Podsakoffet al. (1996), study the relationship between OCB with group performance. Followed by Yoon and Suh (2003), Bogler and Somech (2005) who found that OCB effect group performance improvement and organizational performance.

Van Dyne et al. (1994), Turnley and Bloodgood (2002), developed a relationship between OCB framework, social capital, and organizational performance. Dimensions of OCB include loyalty, obedience, functional participation, social participation and advocacy participation, social capital interacts with an organization that is a structural dimension, relational dimension and cognitive dimension has a significant impact on organizational performance improvement. While Ariani (2008) in his research found that OCB is a positive behaviors in the workplace that supports individual performance and organizational effectiveness. For behavior outside a role to play, in fact OCB can not be separated from the work habits required in the job or in accordance with the role it plays. Organization implemented it inemployee performance appraisal and set a standard to assess employee performance. In addition, organizations can encourage employee positive behavior.

Based on the above previous studies, we formulate the following research questions:

1. Is there a positive and significant impact of personality on OCB and performance of lecturers at Public University in Makassar South Sulawesi?

2. Is there a positive and significant impact of organizational commitment on OCB and performance of lecturers at Public University in Makassar South Sulawesi?

3. Is there a positive and significant impact of job satisfaction on OCB and performance of lecturers at Public University in Makassar South Sulawesi?

4. Is there a positive and significant impact of organization support on OCB and performance of lecturers at Public University in Makassar South Sulawesi?

5. Is there a positive and significant impact of OCB on performance of lecturers at Public University in Makassar South Sulawesi?

6.

\section{Methodology}

This study used an explanatory pattern study intends to explain the position of the variables studied and the relationship between one variable with another (Sugiyono, 2004). The population in this study is lecturerswho are active on duty in the three state universities in Makassar, South Sulawesi-Indonesia. The total sample of 300 lecturers drawn proportionately from each university, decided using Slovin method (Umar 2004).

\subsection{Population and Research Sample}

\begin{tabular}{|c|l|c|c|}
\hline No. & Higher Education & Number of Lecturers & Sample \\
\hline 1 & HasanuddinUniversity & 1727 & 173 \\
\hline 2 & State University of Makassar & 872 & 81 \\
\hline 3 & Islamic State University of Makassar & 552 & 46 \\
\hline \multicolumn{2}{|c|}{ Number } & $\mathbf{3 1 5 1}$ & $\mathbf{3 5 2}$ \\
\hline
\end{tabular}

\subsection{Instrument}

To synthesize the data,researcher used questionnaires according to the study variables, namely personality, job satisfaction, commitment organisasioanal, organizational support, organizational citizenship 
behavior and performance tailored to the object of study. The first information age, year, gender, education last, faculty, department, and class rank.

Phase 1. Personality measure with 14 items using a Likert scale questions, answer choices are strongly disagree, disagree, disagree, agree and strongly agree. Item questions adapted from Costa \& McCrae (1992).

Phase 2. Measuring job satisfaction with 14 question items developed by Schnake (1983) using a Likert scale

Phase 3.Measuring organizational commitment using the 12 item Likert scale questions TODD. Question adopted based on a questionnaire that is developed by Mayer and Allen (1991).

Phase 4.Measuring organizational support using 8 items Likert scale. The questionnaire was developed by Rhoades \&Eisenberger (2002), Wayne (2002).

Phase 5. OCB measures with 15 items based on a Likert scale pertayaan. The question was adopted from 1998 Organ and Allison 2001.

Phase 6.Measuring the performance of the 8 items using Likert scale questions. Questions adopted from the implementation of The Plague of Higher Education originally termed Tri Dharma PerguruanTinggi, guidelines established by the Indonesian Directorate of Higher Education of Indonesia in 2010 and Decree No. Menkowasbangpan.38/Kep/MK. Waspan/8/1999.

\section{Result}

Based on the model spesific modified in the following table:

4.1 Test results Goodness of Fit IndicesOverall Model

\begin{tabular}{|c|c|c|c|}
\hline Goodness of fit index & Cut-off Value & Hasil Model* & Keterangan \\
\hline$\chi^{2}-$ Chi-square & A small expected & $651,010>(0,05: 172=203,601)$ & Marginal \\
\hline Probability & $\geq 0.05$ & 0.000 & Marginal \\
\hline CMIN/DF & $\leq 2.00$ & 3,785 & Less good \\
\hline RMSEA & $\leq 0.08$ & 0.097 & Less good \\
\hline GFI & $\geq 0.90$ & 0.833 & Marginal \\
\hline AGFI & $\geq 0.90$ & 0.776 & Marginal \\
\hline TLI & $\geq 0.92$ & 0,845 & Less good \\
\hline CFI & $\geq 0.92$ & 0.872 & Less good \\
\hline
\end{tabular}

Source: Hair (2006), Arbuckle (1997)

The evaluation shows the model of the eight criteria of goodness of fit indices only three who do not meet the criteria but the AGFI value is approaching a critical value, while the value of the probability chi_square and this was due to a very large sample of the 300 so sig probability can not be calculated (Hair et all., 2006) so that it can be concluded that the model as a whole can be said to have been in accordance with the data and can be analyzed further.

\subsection{Testing Hypotheses and Discussion}

\begin{tabular}{|c|c|c|c|c|c|c|c|c|}
\hline \multirow[t]{2}{*}{ HIP } & \multirow{2}{*}{\multicolumn{2}{|c|}{ Independent Variables }} & \multirow{2}{*}{\multicolumn{2}{|c|}{ Dependent Variables }} & \multicolumn{4}{|c|}{ Direct Effect } \\
\hline & & & & & Standardize & CR & $p$-value & Information \\
\hline H1 & \multicolumn{2}{|l|}{ Personality } & \multicolumn{2}{|c|}{$\mathrm{OCB}$} & 0.353 & 2,105 & 0,034 & Significant \\
\hline $\mathrm{H} 2$ & \multicolumn{2}{|c|}{ Organizational Commitment } & \multicolumn{2}{|c|}{ OCB } & 0,023 & 0.124 & 0.902 & Nonsignificant \\
\hline $\mathrm{H} 3$ & \multicolumn{2}{|l|}{ Job Satisfaction } & \multicolumn{2}{|c|}{ OCB } & 0,483 & 2.876 & 0,004 & Significant \\
\hline $\mathrm{H} 4$ & \multicolumn{2}{|c|}{ Support Organizations } & \multicolumn{2}{|c|}{ OCB } & 0.677 & 2,740 & 0.009 & Significant \\
\hline H5 & \multicolumn{2}{|l|}{ Personality } & \multicolumn{2}{|c|}{ Performance } & 0,646 & 2,182 & 0,028 & Significant \\
\hline H6 & \multicolumn{2}{|c|}{ Organizational Commitment } & \multicolumn{2}{|c|}{ Performance } & 0.228 & 2,021 & 0,045 & Significant \\
\hline $\mathrm{H} 7$ & \multicolumn{2}{|l|}{ Job Satisfaction } & \multicolumn{2}{|c|}{ Performance } & 0.370 & 2,047 & 0,041 & Significant \\
\hline $\mathrm{H} 8$ & \multicolumn{2}{|c|}{ Support Organizations } & \multicolumn{2}{|c|}{ Performance } & 0.872 & 2,061 & 0,039 & Significant \\
\hline $\mathrm{H} 9$ & \multicolumn{2}{|l|}{ OCB } & \multicolumn{2}{|c|}{ Performance } & 0.516 & 5,264 & 0,000 & Significant \\
\hline \multicolumn{9}{|c|}{ Indirect Effect } \\
\hline \multicolumn{2}{|c|}{ Independent Variables } & \multicolumn{2}{|c|}{ Dependent Variables } & \multicolumn{2}{|c|}{ Intervening variable } & \multicolumn{2}{|c|}{ Standardize } & Information \\
\hline \multicolumn{2}{|c|}{ Personality } & \multicolumn{2}{|c|}{ Performance } & \multicolumn{2}{|r|}{$\mathrm{OCB}$} & \multicolumn{2}{|r|}{0.182} & Significant \\
\hline \multicolumn{2}{|c|}{ Organizational Commitment } & \multicolumn{2}{|c|}{ Performance } & \multicolumn{2}{|r|}{$\mathrm{OCB}$} & & 0.012 & NonSignificant \\
\hline \multicolumn{2}{|c|}{ Job Satisfaction } & \multicolumn{2}{|c|}{ Performance } & & $\mathrm{OCB}$ & & 0,249 & Significant \\
\hline Support C & ganizations & Perf & ance & & $\mathrm{OCB}$ & & 0,349 & Significant \\
\hline
\end{tabular}




\subsection{The Impact of personality on OCB}

There is a positive and significant effect of personality on organizational citizenship behavior. This suggests that a positive personality of lecturers can contribute to the university. Lecturers personality characterized by openness to experience, always try new things, developing ideas and new thinking or innovative and rapidly adapt to changes and new atmosphere. The value of openness to experience is evident from the respondents on average agreed even strongly agree, this indicates that the professors at the three public universities in Makassar have transparency over the case or a new idea which is reflected in the indicators of openness to experience, while agreeableness indicatedto have the lowest value of loading factor.

These results also indicate that professors who work with full responsibility, working in accordance with curriculum planning, honest, positive and always put forward innovative thinking, easy to adapt to the advancement of science, broad-minded, always support the policies of the university would be willing to do the work or activity which exceeds the formal responsibility or conducted OCB.

Associated with the implementation of the Plague of Higher Education in terms of research and development, lecturers are required to always carry out research and development. This also means that lecturers commencing research will look for something new that has not been done by previous investigators. This indicates that the openness to experience personality perfectly suited to the profession as a lecturer. This finding is relevant with research conducted by Organ (1998) and Kumar Bakhshi (2009), Miner (1992)

\subsection{The Impact of Organizational Commitment to OCB}

Numerous empirical study results showed that organizational commitment has no significant influence on $O C B$.This suggests that although lecturers have a strong commitment to the organization, does not necessarily make the lecturers conduct $O C B$.Descriptive variables showed that normative commitment (normative commitment) is an indicator which has the largest mean value which gives information that respondents perceive being loyal to organization basic principles, respondents considered that moving to another organization is an unethical act.Analysis on affective commitmentrevealed that the respondents with a high sense belonging are proud to work at university. The next indicator of ongoing commitment (continuance commitment), gives information that respondents feel loss if they have to leave the organization because theyneed and depends on the organization.

Confirmatory factor analysis results also showed that normative commitment is dominant in building the organizational commitment variable. This proves that the respondents have a high commitment to the organization and assume that leaving the organization is unethical especially considering the status of public servants who carried strongly felt proud for respondent. In addition, lecturers at the beginning of their career are bound to the commitment for a long term career in the university they registered in.

Futher facts revealed in this study that respondents only work to fulfill their obligations as a lecturer, accordingly teaching load, research, community service to the extent to which they reach the standards requirements. some professors who do not carry out the Higher Education Plague. Lecturers are still reluctant to develop themselves or to give specific guidance on helping students or other professors and lecturers prefer to take the time to family matters or find a second job outside campus that can provide additional income and various facilities.

Another fact found from the respondents that lecturers with Phd feel appreciated when given a structural position. In the mean time, there are a lot of promising job offers or positions outside campus in terms of benefits and facilities, therefore lecturerstend to take the outside job intead of getting involved in OCB.

The results are consistent with Alotaibi (2001) who did research on the antecedents of OCB, namely job satisfaction, organizational commitment, and perceptions of organizational support to the government employees in Kuwait who found that perceptions of organizational support OCB temporary effect on job satisfaction and commitment has no effect on OCB . Similarly, William and Anderson (1991), which suggests that organizational commitment has no effect on $O C B$. This is possible because the respondent in question the status of government employees where duties and responsibilities have been clearly defined therefore lecturers generally consider it not necessary to go beyond the formally stated obligations.

\subsection{TheImpact of Job satisfactionon OCB}

Job satisfaction has a positive and significant influence on $O C B$. This suggests that lecturers who experienced job satisfaction will be compelled to show the behavior of OCB. Job satisfaction variable and intrinsic satisfaction indicators present that lecturers were satisfied with the learning opportunities domestic and abroad provided by the university, the opportunity to attend both national and international seminars, involved in reseaches, perceived freedom in learning process, guiding students' final assignment and Field Work Experience $(\mathrm{CCN})$. Also to becomeacademic advisor and to participate in decisions making related to the development of the university as well as other duties as lecturers, perceived as prestige work. All in all, these good benefit and opportunity leads university lecturers to commence OCB. 
In study on university lecturers, it is found that job satisfactionis an important determinant that drives a person to exhibits behavior on OCB. Satisfied individuals tend to interpret work and tasks as meaningful therefore they perform with high responsibility and integrity. There is almost no debate among researchers on the effect of job satisfaction on OCB (Podsakoffet al., 2000). These findings support the results of previous studies conducted by Yoon and Suh (2003), Begum (2005) and Kim (2006), Alotaibi (2001), Gonzales and Garazo (2006), Foote and Tang (2008) who found that job satisfaction affects significantly on employee OCB. William and Anderson (1991) found that in intrinsic and extrinsic satisfaction influence OCB, as Bolon (1997), Konovsky and Organ (1996) also suggested effect of job satisfaction on OCB.

The overall test results concluded that job satisfaction haspositive effect on OCB dimensions consisting of: Altruism, Courtesy, sportsmanship, Conscientiousness, and Civic Virtue. These results imply that all dimensions of OCB can be enhanced if members of the organization can achieve job satisfaction.

\subsection{The Impact of Organizational Support on OCB}

The test results in this study found that organizational support variable has effect positive and significant on OCB. This suggests that the higherorganizational support provided by university, the more it will create and or increase extra-role behavior or OCB among university lecturers.

Organizations support such as fairness, justice, appreciation on achievement, support on activities,condusiveworking conditions, quality and fair reward play an important role in improving OCB among lecturers. As shown in the analysis, fairness has the highest loading factor. Rhoades and Einsenberger (2002), George and Brief (1992) stated that perceived organizational support at higher levels will increase extrarole behavior $(\mathrm{OCB})$ in such where employee help co-workers, taking measures to protect the organization from risk, contributes constructive ideas, as well as trying to increase knowledge and skills that are beneficial to the organization. Shore and Wayne (1993), Kaufman (2001) and Bell (2004), Asgariet al. (2008) found that perceptions of organizational support to be a predictor of organizational citizenship behavior (OCB) and positively related to performance and OCB.

Based on the above, it can be concluded that the organizational support play significant role on OCB and that the higher organizational support means higher OCB.

\subsection{The Impact of Personality on Performance}

The results of this study indicate that personality have contributed to the performance of the lecturer. Lecturers with goodpersonality indicators of extraversion, agreeableness, emotional stability, openness to experience performance well teaching and learning and other activities.

Good personality will greatly affect the behavior of lecturers. This is crucial considering that lecturershold a central role in alluniversity activitiesespceallyin knowledge transfer process. Lecturers with good personality expected to improve their performance which in turn will influence the university performance. This is consistent with the results of Barrack and Mount (2006), Humphreys and William (1984) and Hurtz and Donovan (2000), Nikolaou (2003), Lau and Shaffer (1999), Guthrie et.al (1998), Jawahar and Carr, 2007, which stated that the big five personality dimensions have a significant impact on performance.

\subsection{Effect of Job Satisfaction on Performance}

The results of this study found that job satisfaction has a positive and significant impact on performance. This suggests that satisfied lecturers work will continue to improve their performance. Job satisfaction variable have contributed to the performance of the lecturer. Lecturers's job satisfaction indicated by social satisfaction, extrinsic and intrinsic satisfaction which canall affect the performance of lecturers.

When lecturer satisfied with the given fasitity, comfortable with the organization and work environment, they will work professionally, besides they willrealize the need to develop themselves and gain knowledge by doing research and participating in various programsto improve knowledge, abilities and skills that will finally lead to improved performance. Furthermore, job satisfaction can stimulate employee morale and loyalty, otherwise without employees job satisfaction employee will be reluctant to work and think to switch jobs (Robbins: 1996).

The relationship between job satisfaction and performance presented by Porter-Lawler (Luthans 1998) which states that the performance of intrinsic and extrinsic performance affects job satisfaction. Until recently there is no conflict about job satisfaction affect performance or performance affect job satisfaction.

This study is in line with that proposed by Vroom (1960) and Strauss (1968), Schleicher (2004), Wanous (2004) about the relationship between job satisfaction and performance stating that productivity can be improved through increased job satisfaction where job satisfaction can encourageemployee to improve productivity. 


\subsection{Effect of organizational support on Performance}

The results of this study indicate that organizational support variables have contributed to the performance of lecturers. Organizations support with justice indicators (with item: lecturers feel that the organization continues to be fair and appreciate the work achieved success), supervisor support (with item: lecturers feel that the organization has always supported positive activities, want to listen to the problems faced and willing to help if there is a problem), reward organization and working conditions (with item: lecturers feel that the organization values achieved success, satisfaction and care about giving recognition to the extra performance). All these variables can affect the performance of lecturers in teaching and learning and other activities.

Lecturers who are being treated fairly by the organization, supported every positive activities undertaken, recognition of achievement and relief when faced with a problem will receive the support of the organization's sense, so that the lecturer will be motivated to give their best result which will directly impact on performance improvement.

This study is in line with Meglino (1989) which suggests that individuals who share the same values with the organization would be easy to interact efficiently with the value system of the organization and more likely to reduce uncertainty and conflict and increase satisfaction and improve performance.

\subsection{The Influence of $\mathrm{OCB}$ on Performance}

OCB has a positive and significant effect on performance of lecturers and support the research hypothesis that lecturers with high OCB will have an increase on performance.This explaines that the increasing helping behavior of lecturers, voluntary activities, follow the development and progress of the organization, participation in campus activities, student grades handed faster than scheduled, being positive about the organization, demonstrated performance exceeding minimum standards, voluntarily support functions of the organization, responsible for the duties and obligation and honesty will be able to improve performance of lecturers at university.

This research was supported by George and Battenhausen (1990), Podsakoff, et al . (1997), Bogler and Somech (2005), Van Dyne et al. (1994), MacKenzie, et, al . (1996), Waltz and Niehoff (1996), Ariani (2008) who found that the behavior that exceeds the standards established organizations can improve performance.

\section{Conclusion}

Personality has a significant and positive impact on organizational citizenship behavior. This means that lecturers will commence extra-role or exceed standard set by the organization when they take their work seriously, open to new things, collaborative and emotionally stable.

1. Organization commitment effect is insignificant on $O C B$. This means that although lecturers have high organizational commitment, it does not necessarily guarantee the lecturer carry extra role for university improvement.

2. Satisfied lecturers at work has a significant and positive effect on $O C B$. This shows that the more satisfied the lecturers either extrinsic, intrinsic or social, the more they will perform extra roles (OCB)

3. Organizational support has a significant and positive effect on OCB. This suggests that the better organization support in terms of rewards, fairness and decent working conditions, the more it will encourage lecturers to carry extra role $(\mathrm{OCB})$

4. Personality has a significant and positive impact on the performance of the lecturer. This means that lecturers will carry out the Higher Education Pledge so called Tri Dharma PerguruanTinggi when they have the ability to collaborate, openness to other people experience and emotional stability.

5. Organizational commitment has a positive and significant effect on the performance of the lecturer. This shows that the performance of the implementation of the Tri Dharma PerguruanTinggiwill get better when supported by a high organizational commitment among lecturers.

6. Job satisfaction has a significant and positive impact on the performance of the lecturer. This indicates that when lecturers are satisfied, either extrinsic, intrinsic and social, they will be able to achieve better performance on the implementation of PT Tri Dharma

7. Organization support has a significant and positive impact on the performance of the lecturer. This means that when the lecturersare treated fairly and rewarded accordingly by the organization, they will be encouraged to better implement PT Tri Dharma

8. OCB has a significant and positive impact on the performance of the lecturer. This means that lecturers who follow the rules and procedures of the organization will be willing to go the extra mile or exceed the responsibilities demanded byuniversity,futher on it will enable the achievement of better performance in implementing the Tri Dharma PerguruanTinggi. 


\section{Limitations \& Recommendation For Further Of Research}

Researchers have been trying to commence a good research to develop a research model of OCB, but can not avoid limitations and drawbacks in the implementation, namely:

1. The research variables were measured based on the perception of the respondents who were also the subject of research that can lead to bias in obtaining the data, especially for measuring personality, OCB, and performance.

2. Personality and commitment of lecturers in this studymaynotreflectthe personality and commitment in general lecturer at universities throughout Indonesia so it can not be generalized. Further research may look at private university lecturers and utilize different variables to measure.

3. OCB and performance of lecturers in this study is local, particular at the State University in the city of Makassar and therefore can not be generalized. In the future, other research can be conducted in other region and or different level of education.

[1] Organ, D.W
[2] Cohen, A. and Vigoda

[3] Konovsky, M.A. \& Pugh, S.D

[4] Podsakoff, P. M., MacKenzie, S. B., \&. Bommer, W. H.

[5] Allison, B. J., Richard Steven Voss, \& Sean Dryer

[6] Comeau, D. J.,\& Griffith, R. L

[7] Wagner, Shaon L \&Rush, Michael C

[8] Castro, C. B., Armario, E. M.,\& Ruiz, D. $\mathrm{M}$

[9] Feather, N. T., \&Rauter, K. A.

[10] Liang, S., Ling, H., \& Hsieh, S

[11] Kumar, K., \&Bakhshi, A.

[12] Elanain, Hossam. M. Abu

[13] Emmerik, IJ.H.v and Euwema.C

[14] King, Eden, B. George, Jennifer M danHebl, Michelle R.

[15] Barrack, R. B \& Mount, M, K

[16] Caligiuri, P. M

[17] Nikolaou, L

Ackfeld, Anna L. \&Coote, Leonard V

[19] Gautam. Thanswor, Rolf van Dick, Ulrich Wagner, Norratam, Upadhyay and Ann J. Davis

[20] Paulin, Michele, Ferquson. Ronald J. Bergeron J

[21] Alotaibi, Adam G

[22] Chen, Zhen Xiong and Francesco, Anne Marie

[23] Cropanzano, R, Rupp, D, Zinta, B, S

\section{References}

1998

2000

1994

1996

2001

2005

2000

2004

2004

2007

2009

2007

2007

2005

2006

2006

2003

2000

2004

2006

2001

2003
OCB: The Good Soldier Syndrome, Lexington Books, Lexington,

Do Good Citizens Make Good Organizational Citizens?An Empirical Examination of the Relationship between General Citizenship and Organizational Citizenship Behavior in Israel, Administration and society, Vol. 32 No. 5, pp 596-625

Citizenship and social exchange. Academy of management journal, vol 37: 656-669

Transformational leader behavior and subtitutes for leadership as determinant of employee satisfaction, commitment, trust, and organizational citizenship behavior. Journal of Management, 22: 259-298 Student Classroom and career success. The Rule of Organizational Citizenship Behavior. Journal of Education for Business, 76(5):282-288 Structural interdependence, personality and Organizational Citizenship Behavior. Personnel Review, 34 (3): 310-330

Altruistic Organizational Citizenship Behavior: Context, Disposition, and Age The Journal of Social Psycology; Jun 2000;140, 3; Proquest Medical Library p.379

The influence of Employee Organizational Citizenship Behavior on Costumer Loyalty. International Journal of ServiceIndusty Management Organizational Citizenship Behavior in Relation to Job Status, Job Insecurity, Organizational Commitment and Identification, Job Stisfaction and work Values. Journal of Accupational and organizational Psycology, 77: $81-94$

The Mediating Effect of leader-Member Exchange Quality to Influence the Relatioship Between Paternalistic Leadersip and Orgnizational Citizenship Behavior. Journal of American Academy of Business

Lingking the 'Big Five' Personality Domain to Organizational CitizenshiBehavior.Journal of Psychological Studies, vol 1, No.2

The Five Factor Model of Personality and Organizational Citizenshi Behavior in United Arab Emirates, Sam Advanced Management Journal Who is Offering a Helping Hand?associations between Personality and OCBs, and the Moderating role of team leader effectiveness. Journal of Managerial Psycologyvol 22 No. 6, pp. 530-548

Linking Personality to Helping Behaviors at Work: An International Perspective Journal of Personality 73:3, June 2005

The Big Five Personality Dimensions and Job Performance: A Meta Analysis, Journal of Personnel Psycology, Vol 44

The Big Five Personality Characteristic as Predictors of Expatriate"s desire to Terminate the Assigment and Supervisor

Fittngiorganization: Examining the Personality-Job Performance Relationship from a New Perspective. Journal of Managerial Psychology.Vol 18.Iss 7, pp. 639-648

An Investigation Into Antecedents Of Organization Citizenship behavior ANZMAC 2000 Visionary marketing for the 21 st Century: Facing The challenge 217Public Personnel Management; Fall 2001;303, ABI/Inform Reseach p.363

Organization Citizenship Behavior Commitment in Nepal, ISBN No: 1 854496204

Service Climate and Organizational Commitment; The Importance of Costumer Linkages. Journal of Business Research 59. Pp 906-915

Antecedent of Organizational Citizenshipp Behavior: A Study Public of Public Personnel in Kuwait, Public Personnel Management, 30(3): 363376

The relationship Between Three Component of Commitment and Employee Performance in China, Journal of Vacation Behvior

The Relationship of Emotional exhaustion to Work Attitudes, Job Performance and Organizational Citizenship Behavior. Journal of Applied Psichology, Vol 88(1) pp. 160-169 


\section{[24] Kim, Sangmook \\ [25] Koys, Daniel J}

[26] Yoon, Mann. Hee, Suh, Jaebeom

[27] Begum, Noorjahan

[28] Gonzales, Jose Valera \&Gazaro, Teresa Garcia

[29] Foote, D.A. and Tang, Thomas. LiPing

[30] Schleicher Deidra J., Watt John D., Greguras Gary J

[31] Rhoades, L. and R. Eisenberger

[32] Asgari, Ali,.Silong, A.D Ahmad, A \&Samah, B. A

[33] Podsakoff, P. M., MacKenzie, S. B., Paine, J. B., \&Bachrach, D. G

[34] Van Dyne, L., Graham, J. W., \&Dienesch, R. M

[35] Ariani, D Wahyu

[36] Mayer. J.P dan Allen. N.J, A

[37] Wayne, S.,J., Shore, L.M., Bommer, W.H. \&Tetrick, L.E

[38] Organ, Dennis W

[39] Hair, J.A., Rolph E. Anderson, Ronald L. Tathtam, William C Black

[40] Miner.A.Sdan moorman.Ch

[41] Bolon, Douglas S

[42] Kaufman, Jennifer.D. Stamper, Cristina. L and Tesluk, Paul.E

[43] Bell, Simon J

[44] Humphreys, Michael, S. William, R

[45] Wanous, John P
2006

2001

2006

2008

2004

2002
Pubic Service Motivation and Organizational Citizenship Behavior in Korea, International Journal of Manpower, vol.27 No.8,2006 pp722-740

The Effect of Employee satisfaction, Organizational Citizenship Behavior, and Turnover on Organization Effectiveness; A Unit-Level, Longitudianal Study Personnel Psychology. Durham; Spring 2001. Vol. 54. Iss. 1; pg. $101,14 \mathrm{pgs}$

Organization Citizenship Behavior and Service Quality as External Effectiveness of Contact Employees, Journal of Business Research 56. Pp 597-611

The Relation Between Social Power and Organizational Citizenship Behavior. The Meditational Role of Procuderal Justice, Organizational commitment, and job Satisfaction in Contex of A Private Commercial Bank in Bangladesh

Structural Relationship between Organizational Service Orientation, Contac Employee Job Satisfaction and Citizenship Behavior, International Journal of Service Industry Management. Vol. 17 No. 1, 2006 pp $23-50$

Job Satisfaction and Organizational Citizenship Behavior Does team commitment make a difference in self-directed teams? Management Decision Vol. 46 No. 6, 2008 pp. 933-947

University of Tulsa Reexamining the Job Satisfaction-Performance Relationship: The Complexity of Attitudes. Journal of Applied Psychology Copyright 2004 by the American Psychological Association, Inc. 2004, Vol. 89, No. 1, pp165-177

Percived Organization Support: A Review of literature. Journal of Applied Psychology 87:698-714

The Relationship Between Organizational Characteristic, Task Characteristic, Cultural Context and Organizational Citizenship Behavior Organizatinal Citizenship Behavior: A critical review of the theorical and empirical literature and suggestions for future research. Journal of Management, 26:513-563

Organizational Citizenship Behavior: Construct Redefinition, Measurement, and Validation. Academy of Management Journal. 37 (4): The Relationship Between Task Performance and Contextual Performance with Job Satisfaction, Commitment, and Personality. Journal of Performance, Vol.1, No.2: 165-181

Three Component Conceptualization of Organization Commitment, Human Resource Management Review, vol 1, 1991, hlm.61-89

The Role of Fair Treatment and Rewards in Perceptions of organizational Support and Leader Member Exchange. Journal of Applied Psycology, vol 87: $590-598$

Organizational Citizenship Behavior. Its Nature, Antecedents, and Consequences. California: Sage Publications, Inc.

Multivariate Data Analysis with Readings, Engelwood Cliffs, NJ: Prentice-Hall, Inc.

The Impac of Organization Memory on a new Product Performance and Creatifity, Journal of Marketing Reseacrh. Vol 31, No. 1, pp 91-106

Organiational Citizenship Behavior Among Hospital Employees: A Multidimensional Analysis Involving Job Satisfaction and Organization Commitment, Hospital \& Health Services Administration; Summer 1997; 42,2; ABI/INFORM Research pg 221

Supportive Organization Make For Good Corporate Citizens? Journal of Manajgerial Issues Vol. XIII No.4 pg.436

Raising the Bar of Cervice Quality; The Role of Sales PersonOrganizational Relationship Organization Citizenship Behavior, Bulent MengucDepartemen of Management University of Melbourne, No. 2, pp $1-22$

Personality, motivation and performance: ATheory of Relationship Between Individual differences and Information Processing. Journal of Psychology, Vol 91(2) p. 153-184

Causal-correlational analysis of the job satisfaction and performance relationship. Journal of Applied Psychology, Vol. 89, No. 1, 165-177 